\title{
Characteristics of Innovative SMEs in Pakistan: A Case Study
}

\author{
Fazli Wadood, Dr. Alina Shamsuddin and Dr. Nor Hazana Abdullah \\ Faculty of Technology Management and Business University Tun Hussein Onn Malaysia \\ 86400, Johor, Malaysia
}

\begin{abstract}
The area of innovation has received much attention from the literature. However the characteristics of innovative SMEs are still unclear. Hence, this research's purpose is to provide a list of comparative analysis between innovative SMEs and ordinary SMEs. This is a qualitative research and 13 interviews have been conducted. This paper reported only one interview. The analysis is using Miles and Huberman (1994) techniques. The finding can be scanned as a guideline for government and policy makers to understand and to be more focus on the innovativeness among SMEs.
\end{abstract}

Keywords: SMEs, Innovation Activities, Innovative Characteristics, innovative SMEs.

\section{INTRODUCTION}

In the economic development of a country, the importance of small and medium enterprises (SME) cannot be underrated. The proper identification of the role of SMEs comes from the G-8 Group meeting (1997) in Denver. The meeting highlighted the significant contribution of the SME sector to employment and dynamism in the most industrialized world. The United Nation Industrial Development Organisation (2002) has put emphasis that this experience can be used for the development and the sustenance of the SME sector in developing countries. The potential of SMEs to promote domestic-led growth in new and existing industries and to strengthen the flexibility of the economy in a competitive and challenging environment are inarguable. Due to their sheer numbers, size and nature of operations, this segment of the economy has received great attention towards acceleration of economic growth and made an important contribution towards productivity and expansion (Syed et al., 2012; Wadood and Shamsuddin, 2012a). It is also considered as a backbone for economic development of a country (Amini, 2004; Radam et al., 2008; Wadood and Shamsuddin, 2012c).

The role of SMEs is recognized all over the world for their contribution. Small enterprises are considered as main driver for innovation, poverty reduction, employment generation and social integration (Subhan et al., 2013). Furthermore, it is also recommended that innovative SMEs are efficiently contributing towards the country economy as a whole. In this regard most of the studies are conducted from various directions to indicate their issues, problems and factors contributing towards their enhancement. Hence, many factors that influence innovation activities are usually national, such as institutional factors, culture and values, and sometimes international, such as technology and knowledge flow across borders (OSLO Manual 2005, IMF, 2008). Due to the fast growing communication such as the internet, firms are able to interact with foreign firms and universities. These communication resources sometimes compel organizations to be innovative. However, international market competition forces the firms to enhance their competencies and effectiveness to develop new product or brought changes to the process and organizational activities (OSLO Manual, 2005). The economic and social development of a country largely depends on the continued launching of new products and new ways of doing business (Wadood and Shamsuddin, 2012, a, c, d). The new arrival of products and services provide employment opportunities; reduce the importing and enhancing the nation's standard of living.

In other words, for anyone who is interested in some of the most basic problems of society, the subject of innovation is relevant (Hage, 1999). Solving basic problems of the society is a way that brings changes to the traditional approach is the basic theme of innovation. Thus, Innovation in its various forms has long been recognized as critical to a firm's competitive advantage (Cooper, 2000; Damanpour and Gopalakrishnan, 2001; Scarborough and Zimmerer, 2002). In a more detail manner, Brogren (2011) stated that "research converts money into knowledge, while innovation converts knowledge into money". Consequently it is important for every organization to innovate (Tidd et al., 2005, Albury 2005). In this regard innovation is not only required for financial gain and easier life, but it is also necessary to make our society healthier and more sustainable.

Due to this changing business environment, SMEs are experiencing increased competition as foreign firms has gained access to local markets, and it is therefore crucial for SMEs to respond efficiently and sustain their competitiveness against both the local and international competitors (Huu and Nhu, 2009). In the present world economy no market is safe from competition and no company can restrict to its home market. Thus, firms have only two basic functions; to know the market demand and to produce new (Innovation) commercially viable product and services. 
Therefore, to maintain and sustain their contribution towards economic development, it is necessary any organization to focus more on innovation (Baldassarri and Saavala, 2006). When a firm wants to make changes in their business operations (Innovation), it is necessary to pinpoint and understand the various nature of innovation. In continuation to the above, Perrin (2000) raised some points with arguments that any firm who wants to be successful in their innovation activities may consider these points; risk (associated with Innovation), expected changes, assessment regarding usefulness, and who will benefit from it. Innovation and innovation enhancement activities are beneficial for small firms as compared to large firms due to their nature of operation. The small organizations know the local customer and markets very well and have close relationship with local customers, which can easily be projected in their organization. Therefore, studying innovation in various directions suggest that innovation is the essence of any organisation in this globalized world and crucial for the enhancement of quality of life. Consequently, it is needed for the government and non governmental agencies to indicate the basic characteristics of innovative SMEs, to be focus on and to provide assistance in their specific area of interest to increase the innovativeness of SMEs.

This paper's objective is to provide an understanding of the characteristics of innovative SMEs compared to ordinary SMEs.

\section{LITERATURE REVIEW}

Innovation is a complex process and it is quite difficult to compute and measure innovation across organizations. Presently in small business research there is no set of measurement to evaluate firm performance (Parker et al., 2010). Thus, the question of what criteria exists to classify 'innovative SMEs' arised. OSLO Manual (2005) has provided a common definition for the innovative SMEs, where according to them, an innovative firm is one that has implemented technologically new or significantly improved products or processes or combinations of products and processes during the period under review. There are no hard and fast rules and fix set of characteristics that differentiate among innovative and non innovative SMEs (Birkinshaw et al., 2011). Moreover, very few empirical studies have focused on factors affecting performance in a small firm (Heimonen, 2013). But researchers are trying to explain the increasing concentration on the factors that lead towards innovation and higher performance. A firm is known to be innovative if it is involved in innovation activities. Innovation activities include all scientific, technological, organizational, financial and commercial steps which actually lead, or are intended to lead, to the implementation of innovations (OSLO Manual, 2005). Moreno and Casillas (2007) stated that there are several reasons to explain the expanding interest in understanding and analyzing the determinants of growth within small and medium sized enterprises especially high growth firms such as size, age, financial structure and existence of idle resources (Non Financial Resources). Currently some studies consider various factors contributing towards firm innovative performance such as, networking and benchmarking (Terziovski, 2003; Massa and Testa, 2004). With regards to benchmarking, Massa and Testa (2004) further emphasizes that this enables a company to compare its practices and performances with others as well as to acquire external explicit and tacit knowledge, which may lead to improvements and innovations. In addition, Chandler et al., (2000) found close analysis of competitors, supervisory and reward system supports to be the most relevant to successful innovative SMEs. Similarly, Salavou et al., (2004) has found that strategic orientation and competitive structure in which a company operates was found to have effects on company innovative performance. According to the study of Salavou et al., (2004), innovative SMEs are planning ahead, having clear and risk taking strategies. Thus risk taking behavior of a firm leads to innovative environment. According to the study by Blumentritt (2004) conducted in American SMEs, innovative firms are quick in decision making and risk taking. Other studies done by Blumentritt (2004) and Mambula and Sawyer (2004) also agreed with all the above arguments such as top management innovative vision, new idea appreciation and clear and right managerial systems. Charney and Libecap (2000) are with the argument that innovative firms are found to have a strong education background of the Owner/manager, which produces self sufficient innovative individuals.

In the innovation literature, emphasis has been put on the organization learning, risk taking, networking, training and benchmarking. In the study of Raymond and St-Pierre (2004), Research and Development activities and organizational learning are the two main contributors towards innovative performance of an organization. According to Barnett and Storey, (2000) innovative firms have a good planning for the training of their employees. Study of Terziovski (2003) shows that to improve their innovative status, SMEs has to have good networking.

In continuation to the discussion above, networking play an important role towards innovativeness of firms and especially scarce resource firms. However, some studies are showing negative results. In this regard, Tidd et al., (2001) conducted a survey in the UK, and found that, although many organizations formed alliances in an effort to reduce the time, cost or risk of R\&D, but they did not get these benefits from their networking and collaboration efforts. 
Laforet and Tann (2006) highlighted the innovative characteristics of SMEs and stated that creating structure reflecting in the effective use of systems and technology and investors in people (currently known as process innovation), promoting a corporate culture, analyzing competitors, developing co-operations and partnerships are the basic characteristics of innovative SMEs. Mahmud and Ahmed (2011), analyze the panel data of Investment Climate Assessment Survey conducted by World Bank in 2002-2007 and use the different proxies to distinguish the innovative firms and described the determinants of innovative manufacturing firms. They divided the innovative characteristics into internal which are significant for innovativeness such as trade status, size and quality of human capital, and on the external side, they are with the conclusion that those firms which are in cluster are found to be more innovative. All over results shows that large and medium organization are found to be more innovative and those firms which are the part of cluster have the advantage over other. However, a background and in-depth understanding is necessary as Leseure (2000) observed, what works in one organization does not necessarily apply to another and managerial practices and organization priority vary from one socio-economic culture to another. In this regard, the field experience of the researcher shows that mostly SMEs of the targeted and other remote area are not familiar with such surveys and mostly these firms are not included in different surveys, hence the available data representing the large and modern firms. Because the researcher visited the science and technology directorate, SMEDA regional office, Industries department KPK, KPK Chamber of commerce, SMEs Bank and other institutions to collect a list of innovative SMEs, but even there were no clear guidelines available to distinguished innovative firms from ordinary firm. As the study of Bashir et al., (2010), shows that there is no frame for innovative SMEs in Pakistan, therefore they used the R and $\mathrm{D}$ as a proxy in his study on the landscape of innovation in KPK. But R \& D has been criticised by many authors such as Flor and Oltra, (2004) and Kleinknecht et al., (2002), with an arguments that many R \& D are failing to produce new product or developed firm process, therefore R \& D are not the actual representative of the innovative firms. The researcher observe in filed that most of the SMEs of targeted area has no proper R\&D department, but still they are considered to be innovative SMEs due to their innovative steps which are new to the firm or new to the area.

The above stated studies shows dissimilar conclusion and results, and proving that there is no hard and fast rules or already specified model/framework that differentiate innovative from non innovative SMEs. It also derived for the literature review that every country and region has their own innovative frame, through which the innovativeness SMEs are measured. Hence, there are diversified natures of arguments among researchers and academics and even among the controlling authorities of SMEs around the world. Some, researchers are arguing that the small sized and younger firms are more likely to be innovative, while some are against and support large organization as the more innovative, due to the fact of are of operation and contextual differences. Thus, there is no clear and generally accepted frame for innovative SMEs. Therefore, this paper explores the characteristics of innovative SMEs in Pakistan, to provide a clearer understanding of the differences between innovative SMEs and ordinary SMEs. The following Table-I, are summarizing the characteristics of innovative SMEs.

Table: 1 Characteristics (Themes) of innovative SMEs

\begin{tabular}{|c|c|c|c|c|c|c|c|c|c|c|}
\hline \multirow[t]{2}{*}{ S. No } & \multirow{2}{*}{$\begin{array}{l}\text { Study/ } \\
\text { Authors }\end{array}$} & \multicolumn{9}{|c|}{ Themes } \\
\hline & & $\begin{array}{l}\text { Usage of } \\
\text { New } \\
\text { Technolo } \\
\text { gy }\end{array}$ & $R \& D$ & $\begin{array}{l}\text { Financial } \\
\text { Commit } \\
\text { ment }\end{array}$ & $\begin{array}{l}\text { Networki } \\
\text { ng }\end{array}$ & $\begin{array}{l}\text { Acquisiti } \\
\text { on Of } \\
\text { Knowled } \\
\text { ge } \\
\text { (External } \\
\& \\
\text { Internal) }\end{array}$ & $\begin{array}{l}\text { Strategic } \\
\text { Orientati } \\
\text { on }\end{array}$ & $\begin{array}{l}\text { Risk } \\
\text { Taki } \\
\text { ng }\end{array}$ & $\begin{array}{l}\text { Management } \\
\text { Innovative } \\
\text { Vision and } \\
\text { Education } \\
\text { Background }\end{array}$ & $\begin{array}{l}\text { Market } \\
\text { Closed } \\
\text { Analysis }\end{array}$ \\
\hline 1 & $\begin{array}{l}\text { Oslo } \\
\text { Manual } \\
(2005)\end{array}$ & 7 & & & & & & & & \\
\hline 2 & $\begin{array}{l}\text { Moreno } \\
\text { and } \\
\text { Casillas } \\
\text { (2007) } \\
\end{array}$ & & & & & & & & & \\
\hline 3 & $\begin{array}{l}\text { Terziovski, } \\
(2003)\end{array}$ & & & & & & & & & \\
\hline 4 & $\begin{array}{l}\text { Massa and } \\
\text { Testa, } \\
(2004)\end{array}$ & & & & & & & & & \\
\hline 5 & $\begin{array}{l}\text { Chandler et } \\
\text { al., (2000) }\end{array}$ & & & & & & $V$ & & & \\
\hline 6 & $\begin{array}{ll}\text { Salavou et } \\
\text { al., } \\
(2004)\end{array}$ & & 7 & & & & & & & \\
\hline
\end{tabular}




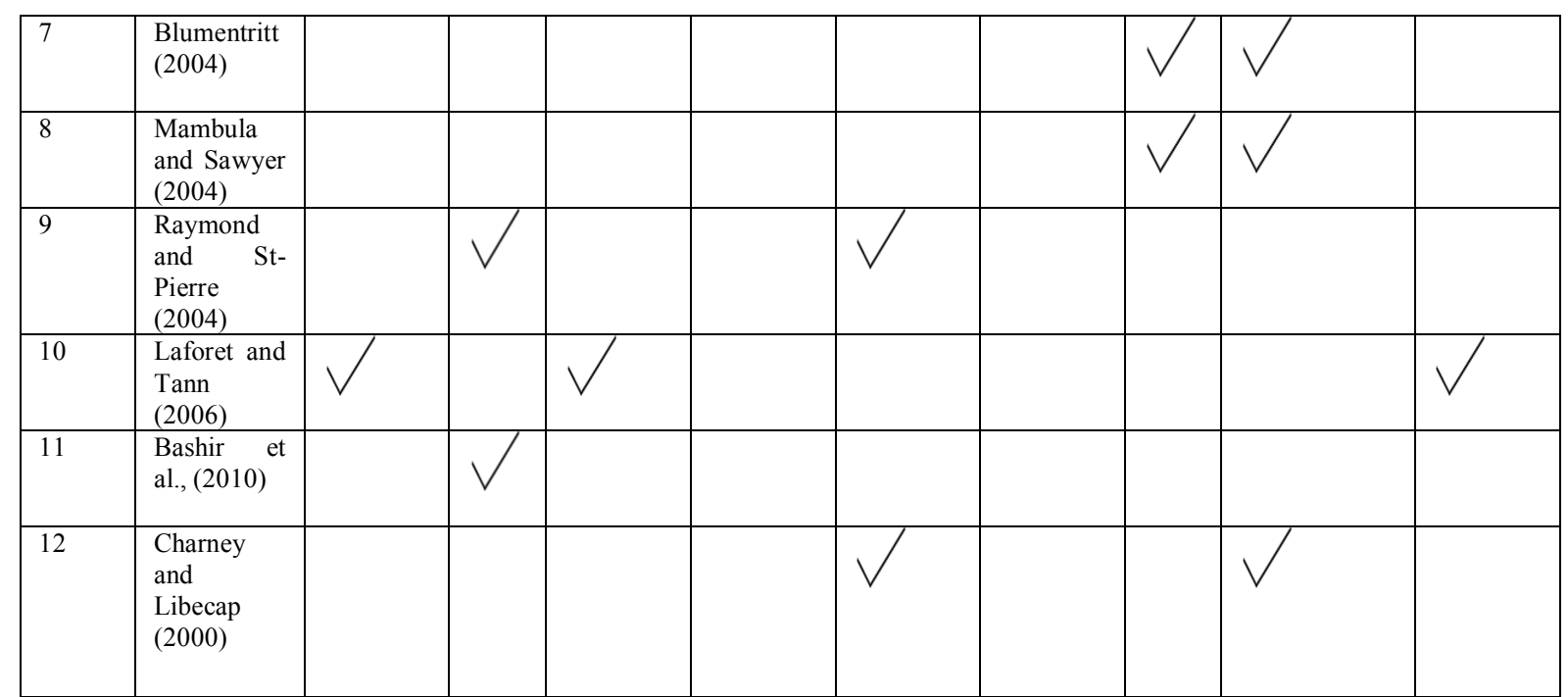

Source: Author

\section{RESEARCH METHODOLOGY}

After a detail literature review and due to explorative nature of the research a qualitative research approach is adopted to explore the unexplored area. The case study approach is adopted to achieve the research aim and objectives. Interviews have been used as the data collection methods.

\section{Data Analysis and Findings}

The data derived from the explorative interviews will be treating step by step according to framework developed by Miles and Huberman (1994) that describing the main phases of data analysis into three steps: 1) data reduction 2) data display and 3) conclusion drawing and verification.

In the first step all the irrelevant and un-meaning information which are not relevant to the research objectives are removed from the data which is also known as filtering. In the second step "data display", which are mainly involves coding, so all the important and most relevant passages and text are grouped and explain their common theme. In the third last step is the most important and critical step in qualitative data analysis. After the identification of general, organized and basic themes the final step is conclusion drawing and results verification. In this regard to validate research findings its need to give high consideration towards findings. So the researcher visits and revisits the data again and again for confirmation of themes which are identified in the second step, to give a through meaning to results.

In this paper we are going to present a preliminary result of the first interview. A detail interview protocol is derived from the available literature to get the relevant, accurate and detail information. The interview booklet (Protocol) and the introductory and authority letter of project director industrial estate Hayat Abad Peshawar KPK, were delivered personally to the owner/manager one week before the final interview with precise introduction. It was meant to enhance the understanding and to get the detail and relevant information, and to explore observed phenomenon. The interview protocol consists of different section followed by a set of questions as suggested by Yin, (2003). In this regard Yin (2003) stats that the uses of a protocol in a case study approach can increase reliability and validity of a research. Yin (2003), further elaborate that case study interview protocol have must compliance the four sections, an overview of case study, field Procedure (Access to case study site and general sources of information), case study questions and a guide for case study report (outline and format of data). However, the interviews are not limited to these stated questions and there is no limitation of questions. The first part of the interview protocol consist of demography and organization characteristics, the second part is consist Level Of Education/ training/ experience (Respondents) and his partner the third part is consist of Product manufactured/ Enhance/ changes in process which further divide into Product, incremental, process, organizational and marketing innovation for easiness and the last part of the interview protocol is consist of fund availability and fund related issues.

\section{IV.1 Company A:}

The interview was conducted with the company manager, on 26-Nov-2012 from 10.00 to $12.00 \mathrm{am}$ ). Company A is a successful innovative SME in a steel and metal production. The company has innovate their process and make the process more easy and reduce the per unit price with increase in their production. And the Company also modifies their existing products that play a significant role in company long term success. 


\section{IV.2 Background and Profile Company A:}

The observed company has been established in 1998 with a very limited production capacity. There are total 30 people are working in the organization, which consist of technical, administrative and general workers. The owner is basically a mechanical engineer, and worked with different small and large origination in Pakistan as well as abroad. The manager who we interview, are also has M.com degree holder and well experienced. Two sons of the owner are also working in the organization and they found active in organization activities and hold different responsibilities. It was the owner vision and experience that he takes the initiative to start the business. The interviewee discussed that due to the technical background the owner look at the market that most of the people are buying the metal and steel form the outside. So a small production with few employees has been started in 1998, and now the organization is at their mature stage and also dealing with exporting to neighbor country. During the interview it was observed that the owner has an innovation vision and the organization hold some distinct skills and abilities. During the visit it was also observed that the obsolete and outdated machinery was removed and placed in a side, which shows the innovative vision of the owner. There is no proper R\&D but in the last of interview when we visit the site the manager also show the under construction research and development lab (where some machine are already installed and some are near to install) and they claimed that in next year our research and development unit will be functional. Because Bashir et al., (2009), survived 304 manufacturing firms to know their innovation level in the area, so they used R\&D as innovative proxy. Their result shows that only $14 \%$ firms have their in house research and development activities. So it confirms that the organization which is selected for interview is a developed among the firms and is involve in different innovative activities and have the future innovative vision.

\section{IV.3 Innovation characteristics of Company A:}

In compliance with Miles and Huberman (1994), framework firstly the irrelevant and repeated data has been deleted and reduced, secondly the data has been classified and combined into themes. Based on the themes developed from the interview suggest 12 characteristics which are leading towards innovative activities of SMEs in Pakistan. This is the initial investigation however; trusted and accurate characteristics of innovative SMEs will be on ground after detail analysis of all 13 cases (interviews). All theses characteristics are precisely discussed in the following:

1. Usage of New Technology: the SME under observation are found to be innovative as found engaged in different innovative activities. The target SME have adopted new machinery which is exported from other countries and also changing the process while adding new technology.

2. Research and Development: there is no formal R\&D department however, the firm involved in different research activities and there is informal $R \& D$ lab, where different parts of machinery are testing and modifying under the supervision of owner. During the site visit the author found under construction research lab, the technical supervisor explains that in near future the lab will start in full pledge.

3. Financial Commitment: the organization showing strong financial position. The data suggest that for innovative activities there is no problem for fund generation. The field observation also showing the same observation because there was a lot of raw material and finished goods. In the last while meeting with some staff members, it observed that the firm is financially stable.

4. Networking: the SME has strong links and ties with different external parties. Strong relation with customer, a good network with skilled personnel and links with large and modern organization. Through these links the firm are getting different information, new ideas and training of employees and development of machinery.

5. Risk Taking: the firm is found to be more risk taking. As the interview suggest that some time the budget not allowing and it's very hard, but still the owner insisting and taking risk to adopt and develop process and products.

6. Management Innovative Vision: Due to the waste experience of the owner/manager the firm is always searching for new idea and applying new techniques. It's also observed in site visit with technical supervisor (when ask about the machinery which were replaced). So it was told that the new machinery is more productive and we adopt it, but still many firms are using the machinery which was replaced.

7. Market Closed Analysis: the interview suggest that the targeted SME has a great focus on market through their marketing personnel and reviewing the competitor position and looking towards market trend.

8. Owner Manager Education and Experience: the owner has Engineering degree (BS) and has a diversified nature of experience with national and multinational organization, while the manager has M.Com degree with 20 year experience in the same industry.

9. External Knowledge Transformation: it has been found that the organization has the ability to quickly and properly transform the external knowledge into organization which is getting through their potential customers, marketing personnel and owner self contact and knowledge. 
10. Employees Commitment: the skilled and general employees are found to be committed with the firm overall mission and vision. As the data shows that the technical staff has personnel links with some modern firms and they are contacting when needed. On the other hand the technical and other skilled employees are always suggesting and try to bring some things new to firm, which are highly appreciated.

11. Organization Strategic Flexibility: the interview and observation suggest that organization are found to changing their strategic direction quickly according to demand from the market (customer), institutional changes and within organization. On the other hand the organization strategy found flexible towards more focus on research activities to solve technical problems.

12. Supplier Closed Links: the firm has a strong links with suppliers, when the firm observes some modification and if not easy to be developed inside contact with supplier. Due to strong links with suppliers the firm different equipments developed. The interviewee argues that the suppliers are sharing the latest updates with us and we have the financial and strategic flexibility to adopt these changes.

\section{Discussion and conclusion}

The land of Pakistan is full from natural resources but due to political in-stability and negligence less attention has been given to these natural resources. On the other hand due to mismanagement form the government and non government authorities and lack of new technology adoption and focusing on their way of doing business the economy is declining day by day. Therefore, to re-establish their economic potential and to restore their loosed status it is recommended to make necessary steps on war putting basis for the innovative performance of SMEs.

In this regard, innovative activities of the observed SME have been derived from detail interview and also highlight the main areas of innovation and improvements. In the preliminary results the authors look at innovative activities and to know the common characteristic of innovative SMEs in Pakistan. However, the final result will be obtained from the detail analysis of the collected data and trusted and tested characteristics of innovative SMEs of Pakistan will be derived.

The targeted case (interview) is showing a detail of innovative activities and their success factor, which indicate a clear difference among the non innovative SMEs. All of the four different categories of innovation (Product, Process, Marketing and Organization) were investigate separately to know the exact innovative activities of the targeted SMEs. Therefore, the more focus has been found in the process innovation as compared to other categories of innovation. The firm considers their process innovation as their first priority and the product innovation is their lowest priority, while marketing and organization innovation is linking with their financial position and availability of professionals.

The objective of this study was to explore the characteristics of innovative SMEs manufacturing firms in Pakistan. The findings of this study (innovative characteristics) with contaxt to pakistani SMEs will provide clear guideline for policy maker, governmnetal agencies and other stakeholders to be focus on to be innovative in their full potential.

\section{REFERENCES}

[1]. Albury, D. (2005). Fostering Innovation in Public Services. Public Money \& Management, 25 (1): 51 -56.

[2]. Amini. A, (2004). The distributional role of small business in development. International Journal of Social Economics, Vol. 31 No. 4.

[3]. Baldassarri, S. Saavala, T. (2006), "Entrepreneurship-educating the next generation of Entrepreneurs" Enterprise Europe, Vol. 22, pp. 16-20.

[4]. Birkinshaw. J, Bouquet. C and Barsoux. J. L (2011), Top ten lesson on the new business innovation, MIT Sloan Management Review 1.

[5]. Blumentritt, T. (2004), "Does small and mature have to mean dull? Defying the ho-hum at SMEs", Journal of Business Strategy, Vol. 25 No. 1, pp. 27-33.

[6]. Bogdan, R. C., and Biklen, S. K. (2007). Qualitative research for education: An introduction to theories and methods (5th ed.). Boston: Pearson.

[7]. Brogren,C. (2011).Malaysian SMETM the SME paper, June 4 To 17, 2011.

[8]. Chandler. G. N, Keller. C and Lyon. D. W, (2000), "Unraveling the determinants and consequences of an innovation-supportive organizational culture", Entrepreneurship Theory and Practice, Vol. 25 No. 1, pp. 59-76.

[9]. Cooper, R.G. (2000). "Doing it right: winning with new products”, IVEY Business Journal, Vol. 64 No. 6, pp. 54-60.

[10]. Damanpour, F and Gopalakrishnan, S (2001), "The dynamics of the adoption of product and process innovation in organizations", Journal of Management Studies, Vol. 38 No. 1, pp. 45-65.

[11]. Hage. J. T, (1999). Organizational Innovation and Organizational Change. Annu. Rev. Sociol. 25:597-622.

[12]. Heimonen. T, (2013), Characteristics of innovative, high growth and highly successful SMEs. Aalto University publication series DOCTORAL DISSERTATIONS 26/2013.

[13]. Huu. L. N and Nhu. D (2009). Role of Parent Control of International Joint Venture in Gaining Competitive Advantage. International Journal of Economics and Finance, Vol. 1 No. 2.

[14]. IMF, International Monetary Fund (2008). http://www.imf.org/external/np/exr/ib/2008/053008.htm.

[15]. Laforet, S and Tann, J (2006), 'Innovative Characteristics of Small Manufacturing Firms', Journal of Small Business and Enterprise Development, vol. 13 , no. 3 , pp. $363-80$. 
[16]. Leseure, M.J. (2000), "Manufacturing strategies in the hand tool industry", International Journal of Operations \& Production Management, Vol. 20 No. 12, pp. 1475-87.

[17]. Mambula, C.J. and Sawyer, F.E. (2004), "Acts of entrepreneurial creativity for business growth and survival in a constrained economy: case study of a small manufacturing firm (SMF)", International Journal of Social Economics, Vol. 31 No. 1, pp. 30-55.

[18]. Massa. S and Testa. S, (2004), "Innovation or imitation? Benchmarking: a knowledge-management process to innovate services", Benchmarking: An International Journal, Vol. 11 No. 6, pp. 610-20.

[19]. Moreno. A. M and Casillas. J. C (2007), "High-growth SMEs versus non-high-growth SMEs: a discriminant analysis" Entrepreneurship \& Regional Development, 19, January (2007), 69-88

[20]. OSLO Manual (2005), (OECD) Organization for Economic Co-Operation and Development. Guideline for collecting and interpreting innovation Data, 3rd Edition.

[21]. Perrin, B (2000), How to-and How Not to- Evaluate Innovation. Presented in the UK Evaluation Society Conference at London.

[22]. Parker, S.C., Storey, D. and Witteloostuijn, A. (2010), "What happens to gazelles? The importance of dynamic management strategy", Small Business Economics, Vol. 35, pp. 203-26.

[23]. Radam. A, Mimi. L. A and Abdullah. A. M, (2008). Technical Efficiency of Small and Medium Enterprise in Malaysia: A Stochastic Frontier Production Model. Int. Journal of Economics and Management 2(2).

[24]. Raymond, L. and St-Pierre, J. (2004), "Customer dependency in manufacturing SMEs: implications for R\&D and performance", Journal of Small Business and Enterprise Development, Vol. 11 No. 1, pp. 23-33.

[25]. Salavou, H., Baltas, G. and Lioukas, S. (2004), "Organisational innovation in SMEs: the importance of strategic orientation and competitive structure", European Journal of Marketing, Vol. 38 No. 9, pp. 1091-112.

[26]. Scarborough, N. and Zimmerer, T. (2002), Effective Small Business Management: An Entrepreneurial Approach, Prentice-Hall, Upper Saddle River, NJ, p. 752.

[27]. Subhan. Q. A, Mehmood. M. R and Sattar.A (2013), Innovation in Small and Medium Enterprises (SME's) and its impact on Economic Development in Pakistan. Proceedings of 6th International Business and Social Sciences Research Conference, $3-4$ January, 2013, Dubai, UAE, ISBN: 978-1-922069-18-4 1. Retrieved on 11-09-2013 http://scholar.googleusercontent.com/scholar?q=cache:yjuI3EX0ITgJ:scholar.google.com/+Innovative+Characteristics+of+Innovati $\mathrm{ve}+$ SMEs + in + Pakistan $\&$ hl $=$ en\&as $s d t=0,5 \&$ as vis $=1$.

[28]. Syed. A. A. S. G, Ahmadani. M. M, Shaikh. N and Shaikh. F. M (2012): "Impact Analysis of SMEs Sector in Economic Development of Pakistan: A Case of Sindh", Journal of Asian Business Strategy, Vol. 2, No.2, pp. 44-53.

[29]. Terziovski, M. (2003), "The relationship between networking practices and business excellence: a study of small to medium enterprises (SMEs)", Measuring Business Excellence, Vol. 7 No. 2, pp. 78-92.

[30]. Tidd. J, Besant. J. R and Pavitt. K, (2001), Managing Innovation: Integrating Technological, Market and Organizational Change, Chichester: John Wiley.

[31]. United Nation Industrial Development Organization (UNIDO) (2002) Corporate Social responsibility: Implication for Small and Medium Enterprises in developing countries (2002) Retrieved on February 28, 2013, from www.unido.org

[32]. Wadood. F and Shamsuddin. A, (2012a), Innovation in VSMEs of Pakistan what Next! OIDA International Journal of Sustainable Development 03:01 (2012).

[33]. Wadood. F and Shamsuddin. A, (2012b), Affect of Retention on Innovativeness of VSMEs In Pakistan. Conference Proceeding Asia-Pacific Business Research Conference 13-14 February, 2012, Kuala Lumpur, Malaysia Available at http://www.wbiconpro.com/412-Fazli.pdf.

[34]. Wadood. F and Shamsuddin. A, (2012c), Key Factors Enhancing Innovativeness Among VSMEs Of Pakistan. Conference proceeding (ICIMTR, 2012), Available at http://ieeexplore.ieee.org/search/searchresult.jsp?newsearch=true\&queryText=KEY+FACTORS+ENH ANCING+INNOVATIVEN ESS + AMONG+VSMES + OF+PAKISTAN $\& \mathrm{x}=24 \& \mathrm{y}=6$.

[35]. Wadood. F and Shamsuddin. A, (2012d), Innovativeness Abilities Of Small Organisations In Pakistan. Confrence proceeding 4th South Asian International Conference on Emerging Knowledge Economy in the 21 st Century: Opportunities \& Challenges, 5-7 December 2012 at PC Burban Muree Pakistan. www.agba.org.pk. 